\title{
統計的手法による橋脚の洗掘防止工の安定度判定手法

\author{
STATISTICAL JUDGEMENT ABOUT STABILITY OF PROTECTION \\ AGAINST SCOUR AROUND PIER
}

\author{
岡田勝也*・村石尚**.国広敏彦*** \\ By Katsuya OKADA, Hisashi MURAISHI and Toshihiko KUNIHIRO
}

\begin{abstract}
The stability of concrete-block work for the protection of the pier against the scour at flood is discussed by the way of the multivariate analysis and the judgement method of the stability for the concrete-block work is proposed.

For the work, the discriminant analysis is executed. In consequence, the discriminant function for the stability with the five variables is induced. Their variables are river width-depth ratio, river depth, friction velocity, river channel radius and block weight. While the adaptability limit about the discriminant function is also defined.

Lastly, the experimental heightening countermeasures of the stability is discussed, and the judgement method about the stability on the concrete-block work is proposed.

Keywords : stability, concrete-block work, scour-protection, discriminant analysis
\end{abstract}

\section{1. まえがき}

鉄道橋梁の下部工は, その経年が 60 年を越える旧式 構造物が数多く，老朽化が進んでいるのが実情である. このような旧式構造物は，もともと根入れが浅いうえに 昭和 40 年代の河川の砂利採取をはじめとする環境変化 による急激な河床低下により，基礎構造物としての安定 度が低下しているものが多い.

こうした中で, 列車走行の安全性を確保しつつ, 地震 や洪水などの異常外力に対しても十分な安全性を有する ように鉄道橋梁を保守管理するためには，基礎構造物自 体の力学的な強度特性や地耐力で代表される土質工学的 特性とともに，洗掘や深掘れで代表される水理学的特性 も考慮する必要がある. そのとき, 橋脚の根入れ不足が 問題になり，橋脚の安定性が損なわれる場合には，しば しば橋脚の洗掘防止工の投入が計画される.しかし，橋 脚の洗掘防止工に関する設計基準は十分には確立されて いない.

本研究は, 橋脚の洗掘防止工の 1 つで, 最近数多く用

* 正会員 工博 鉄道総合技術研究所 主任研究員 ( (185 国分寺市光町 2-8-36)

** 正会員 鉄道総合技術研究所 主任研究員 (同上)

*** 正会員 西日本旅客鉄道 (株) 副課長 (関西高速鉄道 (株) 出向）（干530 大阪市北区大深町 1-1）
いられるようになってきたコンクリートブロック工に着 目し，実際に洪水に遭遇したコンクリートブロック工の 実態調查に基づくデータを用いてその安定性を統計的手 法によって明らかにし，ブロック工の洪水時の安定度判 定手法を提案したものである.

\section{2. 橋脚の洗掘防止工に関する過去の研究経過}

橋脚周辺の局所洗掘に対する防護工法の 1 つとして, 構造物の形状を改善して流況をよくする軽減工法が挙げ られる.これは,橋脚をなるべく流線型にすることによっ て素因となる圧力勾配を小さくしようとするもので，石 原 ${ }^{1)}$, Laursen ${ }^{21}$, Shen ら ${ }^{3)}$ をはじめ古くから多くの研究 がある14). また，橋脚前面の下降流を抑制しようとする 目的で橋脚につばや粗度を付けたり，あるいは橋脚前面 に杭を打設するような付帯構造物を設置する工法に関す る研究は, Laursen ${ }^{2)}$, Shen $ら^{3)}$, 田中 ${ }^{4)}$, 吉川 ${ }^{5)}$, 宇民 ${ }^{6)}$ らによって行われてきた ${ }^{14)}$.これらの橋脚の形状改善に よる工法, 付帯構造物の設置工法は局所的な流れである 渦流を軽減するものである.

これに対し，洗掘される河床領域を直接被覆する工法 が洗掘防護工である.これには,コンクリートやアスファ ルト等で固めてしまう工法と, 捨石やブロックで覆う工 法がある．前者については, 鈴木 ${ }^{7)}$ が橋脚周辺の領域の 
流速などの水理学的検討によりその設計基準を提案する とともに，その有意性を実験によって確かめている．ま た後者の工法に関する研究は捨石工法に端を発する. Breusers ら ${ }^{8)}$ は, Carstens や Hancu の実験なども考虑 し，極限洪水流速の 2 倍に相当する限界流速を有する玉 石を捨石工として使用することを提案している ${ }^{14)}$. 須賀 ら ${ }^{9)}$ はコンクリートブロック工の重量と各種の水理量と の関係を現地の敷設例から明らかにするとともに，数多 くの模型実験を実施し，コンクリートブロック工の重量 と移動限界流速の関係をブロックの種類別に提案し，さ らにブロック群に対する限界流速の割増率を求めた。村 石ら ${ }^{10)}$ は鉄道橋梁の実態調査から橋脚の被災事例をまと め, 根入れ比と根固め工の関係を解析した。 その後, 岡 田ら ${ }^{11}$ は橋脚の洗掘防止工の 1 つであるコンクリートブ ロックエに着目して, 実際に洪水に遭遇した現場データ を集積し，洪水時の安定性に影響を与えると考えられる 要因を一変量あるいは二変量解析により抽出するととも に，それらの要因を用いて主成分分析を実行し，コンク リートブロック工の環境条件のパターン化を行った。ま た村上 ${ }^{12)}$ はコンクリートブロック工の水理模型実験と統 計解析を行い，鉄道橋の洪水時被災機構と安全管理の手 法を明確にし, 中川ら ${ }^{15}$ は洪水時の橋梁の災害形態, 河 道形態と発生機構の立場から被災事例の分析を行った。

こうした研究にもかかわらず, 橋脚の洗掘防止工とし て最近多用されるようになってきたコンクリートブロッ ク工の安定性に関する研究は, 洪水時の河川環境の多様 性と局所流の複雑な水理現象の中で，いまだ汎用的な設 計基準が確立されたとはいいがたいのが実情である.

\section{3. 鉄道橋の洗掘防護工の実態調査とコンク リートブロックエの安全性に及ぼす要因の 抽出}

前述の 2. で述べたように，洗掘防止工の設計基準は 必ずしも明確にはなっていないので，鉄道橋の橋脚防護 工の設計においても, ぼの程度の洪水に対して安定であ るのかという定量的な評価がないまま, 多くは経験的な 方法によって決定されてきたのが実情である.そのため, 洪水時の橋脚の安定性を洗掘防護工に頼らざるを得ない ような場合には，その防災強度を把握することは困難で あった。

そこで, 鉄道橋の洗掘防護工に焦点をしぼり, 洪水に 遭遇した主要な橋梁を中心に全国実態調査を実施した。 実態調査の方法としては, 鉄道橋梁を保守担当する現地 機関にアンケート用紙を配布して, 橋梁と防護工の実態 に関する記入を依頼した。このアンケート用紙は各鉄道 橋梁ごとに作成され，それぞれは，橋梁諸元（上部工， 下部工の構造, 種類など), 河道状況 (河道の種類, 河
道変動の傾向, 砂州の移動・植生の有無, 付近の構造物 の有無), 防護工 (種類, 構造, 施工範囲, 施工年月など) を記入するとともに, 過去の洪水の出水状況 (出水年月, 出水時の水位, 出水時の流量, 出水原因など), そのと きの防護工の変状状況（流出, 沈下, 不陸, 変状なし), 変状後の処置を明記し，さらに以上の事項に関係する全 体略図, 平面図, 河床勾配断面図, 防護工施工図, 河床 材料調査写真, 防護工施工写真なぼを付加したアンケー 卜用紙加構成されている。これらの用紙を現地機関か ら回収して, 整理した後, 後述の多変量解析に使用する データについては詳細な現地調查を実施し，デー夕の精 度を上げることに努めた。

回収した 171 例のうち, 当報告で対象とするコンク リートブロック工は, 全数の約 $45 \%$ を占め（なお，そ の他の防護工は, 蛇篦工・ふとん篭工約 $25 \%$, 張り ンクリート工が $15 \%$ ，シートパイル工約 $10 \%$, 捨石工 約 $5 \%$ であった)，しかもこれは今後もますます多く用 いられることになるものと予想される.

これらのコンクリートブロック工の洪水時の安定性に 及ぼす要因としては, (a) 河川工学的, 水理学的な性状, （b）河川の地形地質的な性状，(c) 洗掘防止工の性状, に分けて考えることができる.

（a）に関するもののうち, 河川工学的には, 洪水中に おかれたコンクリートブロック工の変動は, 中規模河床 変動のスケールである構造物周辺の河床変動が関係して いるものと考えることができる，一般にそれは式（1) のようになる16).

$$
Z_{s} / D=F\left(u_{*} d / \nu, u_{*}^{2} /[(\sigma / \rho-1) g d], h / d,\right.
$$$$
h / \rho, D / d \text {, shape) }
$$

ここに式（1）の右辺第 1 項は砂粒レイノルズ数, 右辺 第 2 項は無次元掃流力 $\tau *$ とよばれ, $u_{*}$ は摩擦速度, $\nu$ は動粘性係数, $\sigma$ は砂の密度, $\rho$ は水の密度, $D$ は橋脚 幅, $h$ は水深, $d$ は砂の粒径, $g$ は重力加速度である. 一方, 河川の水理学的な条件として, 河川の大きさ, 洪 水の規模などを勘案して, ここでは, 河川の幅 $B$, 単 位幅当たりの洪水流量 $Q / B$, 川幅水深比 $B / h$, 水深 $h$, 流速 $v$ などを考慮することにした，その結果，(a) の 河川工学的, 水理学的な性状に関係するものとして, $u_{*}, \tau_{*}, h / d, h, B, v, Q / B, B / h$ とd を選択するこ とにした.

また（b）に関係するものとしては, 河床勾配の逆数 $1 / I$, 河川の湾曲度としてその曲率半径の逆数 $1 / r$ と交 角 $\theta$ を用いることにした.

さらに，(c) の洗掘防護工の性状については，ブロッ クのかみ合わせの程度を考慮した種類のランク付け $i$ と ブロックの重量 $W$ を変量として代表させることにし た. すなわち, ブロック工には多くの種類があるが, ブ 
ロック工が変状し始めたり, 流失する直前には, ブロッ クのかみ合わせや緊結の程度が大きく現象に左右するは ずであるから, かみ合わせや緊結の程度を考慮して分類 した. また，コンクリートブロック工の設置状況として， 平面的な施工範囲や, 河床面からの埋没高 (突出高), 層高などが考えられるが，前者は鉄道橋梁を対象にする かぎりはおおむね線路中心から $2 \sim 3 D$ 以内の範囲にあ ることが多く,また後 2 者は洪水前の状態を正確に記す データもないことから, 多変量の因子としては扱わない ことにした.

結局, 上述の (a), (b), (c) から, 多変量解析を行 うための変量としては, 次式に示す 14 個が選択され, コンクリートブロック工の安定度 $Z$ は式（2）で与え られるものと仮定した。すなわち

$$
\begin{aligned}
& Z=f\left(u_{*}, \tau_{*}, h / d, h, B, v, Q / B, B / h\right. \text {, } \\
& 1 / I, 1 / r, \theta, d, i, W)
\end{aligned}
$$

である.ここに， $u_{*}$ は摩擦速度， $\tau *$ は無次元掃流力, $h / d$ は水深粒径比, $h$ は水深, $B$ は川幅, $v$ は流速, $Q / B$ は単位幅当たりの流量, $B / h$ は川幅水深比, $1 / I$ は河床勾配 (逆数), $1 / r$ は河川湾曲度 (曲線半径の逆 数, $\theta$ は河川湾曲度 (交角), $d$ は河床材料粒径, $i$ は ブロックの種類，W はブロックの重量，である.

これらの因子に基づいて実態調查表に記された項目を 再整理してみると, 記載漏れのデータ, 明らかに間違い のデータなどがあり, 多変量解析の実行に耐え得るデー 夕数は 51 例になった.

\section{4. 判別分析の実行}

鉄道橋梁のコンクリートブロック工の実態調査におい て，コンクリートブロック工が洪水中でも流失して逸散 することなく，ブロック相互が不陸したり，不等沈下を 起こすなどの変状を生じなふったものを安全のグループ $G_{1}$ 亡し, 洪水中に流失したり, かみ合わせがはずれて 洪水前の敷設状況を維持できず，不陸・沈下などの変状 が発生したものを流失したグループ $G_{2}$ と定義する. そ して，3.に示した $n=14$ 変量を用いて判別分析を実行 し，コンクリートブロック工の安定性解析を行う.なお 使用したデー夕数は前述のように 51 例であるが，これ らのデータをアンケート調査結果と, 個々に実施した詳 細調查結果に基づき整理すると，各母集団 $G_{1}$ と $G_{2}$ の デー夕数 $N$ はそれぞれ 34 デー夕と 17 データである. すなわち, 判別解析に用いる変状データは全データの $33.3 \%$ である. 一方このデータの原データである 3. で述 ベた全国実態調査に基づく洪水に遭遇した 171 例の洗掘 防護工に対して，被災を受けた防護工の確率は $30.4 \%$ であった.これは鉄道橋梁における洗掘防護工の洪水時 の一般的な被災確率であると考えられるが，上述の判別解
表一1 各変量の平均值 $\mu_{a, i}$

\begin{tabular}{|c|l|l|l|c|}
\hline & $G_{1}$ (安全) & $G_{2}$ (流失) & $G_{1}+G_{2}$ & 単 位 \\
\hline $1 / I$ & $5.13 \times 10^{2}$ & $3.30 \times 10^{2}$ & $4.52 \times 10^{2}$ & 1 \\
\hline$h$ & 4.60 & 5.62 & 4.94 & $\mathrm{~m}$ \\
\hline$B$ & $1.44 \times 10^{2}$ & $1.99 \times 10^{2}$ & $1.63 \times 10^{2}$ & $\mathrm{~m}$ \\
\hline$d$ & $2.92 \times 10^{1}$ & $3.06 \times 10^{1}$ & $2.96 \times 10^{1}$ & $\mathrm{~mm}$ \\
\hline$v$ & 3.81 & 5.05 & 4.22 & $\mathrm{~m} / \mathrm{s} \mathrm{ec}$ \\
\hline$\tau_{*}$ & 0.55 & 0.60 & 0.56 & 1 \\
\hline$B / h$ & $3.30 \times 10^{1}$ & $4.11 \times 10^{1}$ & $3.57 \times 10^{1}$ & 1 \\
\hline$h / d$ & $5.23 \times 10^{2}$ & $2.93 \times 10^{2}$ & $4.46 \times 10^{2}$ & 1 \\
\hline$u_{*}$ & 0.35 & 0.47 & 0.39 & $\mathrm{~m} / \mathrm{s} \mathrm{ec}$ \\
\hline$Q / B$ & $1.30 \times 10^{1}$ & $1.86 \times 10^{1}$ & $1.49 \times 10^{1}$ & $\mathrm{~m}^{3} / \mathrm{sec} / \mathrm{m}$ \\
\hline $\mathrm{i}$ & 2.79 & 3.00 & 2.86 & - \\
\hline$W$ & 3.05 & 2.20 & 2.77 & $\times 10.2 \mathrm{kN}$ \\
\hline $1 / r$ & $2.22 \times 10^{3}$ & $4.60 \times 10^{4}$ & $1.64 \times 10^{3}$ & $1 / \mathrm{m}$ \\
\hline$\theta$ & $4.97 \times 10^{1}$ & $2.21 \times 10^{1}$ & $4.05 \times 10^{1}$ & $\circ$ \\
\hline
\end{tabular}

表一2 各変量の標準偏差 $\sigma_{a, i}$

\begin{tabular}{|c|l|l|l|c|}
\hline & $G_{1}$ (安全) & $G_{2}$ (流失) & $G_{1}+G_{2}$ & 単 位 \\
\hline $1 / I$ & $9.10 \times 10^{2}$ & $4.33 \times 10^{2}$ & $7.87 \times 10^{2}$ & 1 \\
\hline$h$ & 1.38 & 2.23 & 1.70 & $\mathrm{~m}$ \\
\hline$B$ & $1.15 \times 10^{2}$ & $1.23 \times 10^{2}$ & $1.17 \times 10^{2}$ & $\mathrm{~m}$ \\
\hline$d$ & $1.67 \times 10^{1}$ & $1.59 \times 10^{1}$ & $1.64 \times 10^{1}$ & $\mathrm{~mm}$ \\
\hline$v$ & 1.60 & 2.32 & 1.87 & $\mathrm{~m} / \mathrm{sec}$ \\
\hline${ }^{*}$ & 1.06 & 0.57 & 0.93 & 1 \\
\hline$B / h$ & $2.33 \times 10^{1}$ & $2.84 \times 10^{1}$ & $2.51 \times 10^{1}$ & 1 \\
\hline$h / d$ & $1.29 \times 10^{3}$ & $4.02 \times 10^{2}$ & $1.08 \times 10^{3}$ & 1 \\
\hline$u_{*}$ & 0.14 & 0.24 & 0.18 & $\mathrm{~m} / \mathrm{sec}$ \\
\hline$Q / B$ & 8.47 & $1.46 \times 10^{1}$ & $1.09 \times 10^{1}$ & $\mathrm{~m}^{3} / \mathrm{sec} / \mathrm{m}$ \\
\hline $\mathrm{i}$ & 1.61 & 1.62 & 1.61 & - \\
\hline$W$ & 2.71 & 1.26 & 2.33 & $\times 10.2 \mathrm{kN}$ \\
\hline $1 / r$ & $3.14 \times 10^{-3}$ & $1.20 \times 10^{-3}$ & $2.67 \times 10^{-3}$ & $1 / \mathrm{m}$ \\
\hline$\theta$ & $4.39 \times 10^{1}$ & $3.91 \times 10^{1}$ & $4.24 \times 10^{1}$ & $\circ$ \\
\hline
\end{tabular}

析に用いる変状データの確率 $33.3 \%$ にほぼ相当する.

各変量 $x_{i}(i=1, n)$ の平均値 $\mu_{a, i}$ と標準偏差 $\sigma_{a, i}$ は 母集団 $G_{a}(a=1,2)$ ごとに表一1，2のようにまとめら れる. 母集団 $G_{1}$ と $G_{2}$ において, 平均值のみを比較す れば, 河床勾配の逆数 $1 / I$, 水深粒径比 $h / d$, ブロック 重量 $W$, 河道曲率半径の逆数 $1 / r$, とその交角 $\theta$ は $G_{1}$ の方が大きく, 水深 $h$, 川幅水深比 $B / h$, 流速 $v$, 摩 擦速度 $u_{*}$, 単位幅流量 $Q / B$ は $G_{2}$ の方が大きくなって おり, また河床材料粒径 $d$, 無次元掃流力 $\tau *$, ブロッ クの種類の平均値は $G_{1}, G_{2}$ においてほぼ等しい値を有 する.

さて, 上述の 14 個の各変量が洪水時のブロック工の 安定性にどのような重みを有しているかは，表一1 と表 一2からは判定することはできない.一方, ブロック工 の安定度判定法としては，より少ない変量で安定度が判 定できれば現場での適用に有効なものとなろう.そこで, 判別解析の実行においては, 変量を逐次選択しながら最 適の判別関数を求めていくStepwise-method の 1 つで ある変数増減法を用いることにした。 その結果, 14 個 
の変量から 5 変量が選択され, 次の線形判別関数が求め られた. すなわち, 摩擦速度 $u_{*}(\mathrm{~m} / \mathrm{s})$, 河道曲率半径 の逆数 $1 / r(1 / \mathrm{m})$, ブロック重量 $W(10 \mathrm{kN})$, 水深 $h$ (m) と川幅水深比 $B / h$ を用いて

$$
\begin{aligned}
Z= & -4.47 u_{*}+153 / r+0.177 W-0.343 h \\
& -0.0218 B / h+3.465 \ldots \ldots \ldots \ldots \ldots \ldots \ldots \ldots \ldots \ldots \ldots
\end{aligned}
$$

が得られた. 式（3）は母集団 $G_{1}$ と $G_{2}$ の全母集団に 対する $Z$ の変量が 0 ，分散が 1 になるように正規化さ れたものである.なお, 式 (3) の右辺に示される変量 の順に判別式 $Z$ に与える影響は小さくなっていく．す なわち $u_{*}$ がマハラノビスの距離に最も大きい影響を与 え, 選ばれた 5 変量のうちでは $B / h$ が最も小さいこと になる.これら 5 変量によって母集団 $G_{1}$ と $G_{2}$ の 2 群 の判別ができるかどうかの検定は,

$$
F=(f-p+1) / p f \cdot n_{1} n_{2} /\left(n_{1}+n_{2}\right)
$$

が自由度 $(p, f-p+1)$ の $F$ 分布をすることを用いて行 われる.ここに $n_{1}$ と $n_{2}$ は母集団 $G_{1}$ と $G_{2}$ のデー夕数, $f=n_{1}+n_{2}-2$ であり, $p$ は変量数である. 式 $(3)$ で は $n_{1}=34, n_{2}=17, p=5$ であり，自由度 $(5,45)$ に 対して $F=3.62$ となる. $F$ 分布 $1 \%$ 点においては $F_{0.01}$ $=3.47$ であり，危険率 $1 \%$ において母集団 $G_{1}$ と $G_{2}$ の 2 群の判別は有意亡なる.

さて, 式 $(3)$ の 5 変量のうち, $u_{*}, h$ と $B / h$ の係 数は負であるから, 摩擦速度, 水深と川幅水深比が大き くなれば $Z$ の值は小さくなり，コンクリートブロック 工の流失の危険が増加することになる．逆に $W$ と $1 / r$ の係数は正であるから, ブロック工の重量が大きく, 河 道曲率半径が小さくなればなるほど $Z$ の值は大きくな り，ブロック工の安定性は向上することを示している.

こうした傾向は 3. で述べた一変量解析の結果と定性的 に一致する.

式 ( 3 ) に基づく安全なグループ $G_{1}$ と流失したグルー プ $G_{2}$ の $Z$ の平均值は $Z_{G 1}=0.510, Z_{G 2}=-0.993$ であ

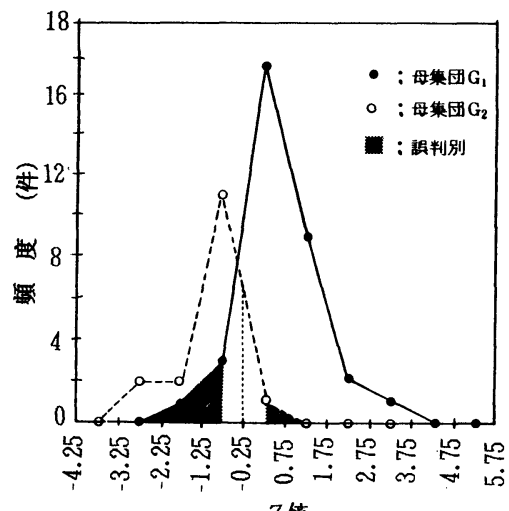

Z值

\begin{tabular}{|c|c|c|c|c|}
\hline 判別 & 正答率 & 判 & 別 & 正 规分布 \\
\hline 母集団 & (\%) & 安 全 & 硫 失 & 正率 (\%) \\
\hline$G_{1}$ 安 全 & 85.3 & 29 & 5 & $81.2 \%$ \\
\hline $\mathrm{G}_{2}$ 流 失 & 94.0 & 1 & 16 & $81.2 \%$ \\
\hline$G_{1}+G_{2}$ & 88.2 & 30 & 21 & $81.2 \%$ \\
\hline
\end{tabular}

図一1 母集団 $G_{1}$ と $G_{2}$ の $Z$ 值の頻度分布
表一3 判別分析の正答率

り，その頻度分布は図一1のようになる． $G_{1}$ と $G_{2}$ の標 準偏差は， $\sigma_{G 1}=0.998 ， \sigma_{G 2}=0.843$ となるから，ミニマッ クス解による判別点 $Z_{k}$ は,

$Z_{k}=\left(\sigma_{G 1} Z_{G 2}+\sigma_{G 2} Z_{G 1}\right) /\left(\sigma_{G 1}+\sigma_{G 2}\right)$

から， $Z_{k}=-0.254$ となる.このとき, 誤判別の確率は 表一3のようになるが，グループ $G_{1}$ (安全) でありな がら流失と判別されるのは $14.7 \%$ であり，グループ $G_{2}$ (流失) でありながら安全と判別されるのは $6.0 \%$ である．すなわち正答率でいえば，前者で $85.3 \%$ ，後 者で $94.0 \%$ であり，全体でいえばコンクリートブロッ ク工の 51 例中, 44 件は正しい判別解を得ることができ, $88.2 \%$ の正答率を確保できそうである.なお，図一1 を正規分布としたときの正答率は $81.2 \%$ となる.

図一1では判別点を $Z_{k}=-0.254$ としているが，これ を $Z_{k}=0$ となるように変形すれば，新しい判別関数 $Z_{0}$ は,

$$
\begin{aligned}
& Z_{0}=-4.47 u_{*}+153 / r+0.177 W-0.343 h \\
& -0.0218 B / h+3.719
\end{aligned}
$$

と置くことができ,

$$
\left.\begin{array}{l}
Z_{0}>0 \cdots \cdots \cdot \text { 安全 } \\
Z_{0} \leqq 0 \cdots \cdots \cdot \text { 流失 }
\end{array}\right\}
$$

なるコンクリートブロック工の安定性に関する判別関数 が得られた.

\section{5. 判別関数の適用限界}

前述の式（6）の判別関数は統計的に算出されたもの であり，おのずと適用限界を有するものである.ここで は各変量の適用限界について考察する.

\section{（1）摩擦速度 $\boldsymbol{u}_{*}$}

判別関数の第 1 項は $u_{*}$ であるがその頻度分布は図一

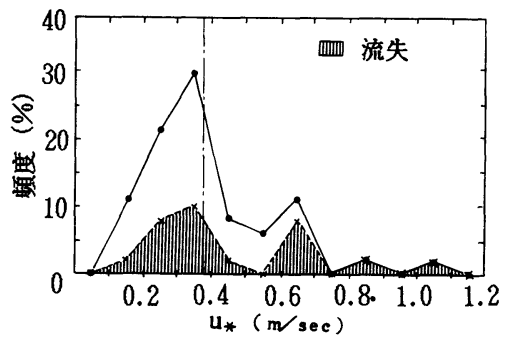

図一2 摩擦速度 $u_{*}$ の頻度分布 
2 に示すように, $0.1 \sim 1.1 \mathrm{~m} / \mathrm{s}$ に及んでいる. $u_{*}$ が大 きい橋梁は, 急勾配で, 水深の大きい領域のものである. 図一2 に示す統計データとして $u_{*}>0.7$ に位置するのは 2 例しかなく，これら 2 例のブロックは流失したグルー プ $G_{2}$ に属しており, 判別結果は正答を示した。一方, 流失しなかったグループ $G_{1}$ はすべて $u_{*}<0.7$ であり, データに偏りがみられる．これらを考慮して摩擦速度の 適用限界を $u_{*} \leqq 0.7 \mathrm{~m} / \mathrm{s}$ とするのがよい.

\section{（2） 河道曲率半径 $r$}

判別関数の第 2 項は $r$ の逆数に比例する. 一方, 現 実に施工されているブロックの重量 $W$ は図一3のよう にいくつかの例外を除き $60 \mathrm{kN}$ 程度以下であるが, 式

（6）の係数を比較することにより，W=60 kN に相当 する河道曲率半径は $r=144 \mathrm{~m}$ である. すなわち判別関 数の $B / h, h, u_{*}$ が同じ条件ならば， $r \leqq 144 \mathrm{~m}$ は $W>$ $60 \mathrm{kN}$ の重みを有することになる，したがって $r$ が小 さくなりすぎると式（6）の $Z_{0}$ はかなり小さくなり， 安全過ぎる傾向を与えることになる．この傾向を判別分 析の統計データからみてみると, $r<150 \mathrm{~m}$ の例は 3 例 あり，これらすべては安全グループ $G_{1}$ に属しており， 判別結果も安全となっている. 以上を考慮しブロック重 量 $W$ との兼ね合いから河道曲率半径の適用限界を $r \geqq 150 \mathrm{~m}$ とした.

\section{（3）ブロック重量 W}

ブロック重量 $W$ は, 判別関係の中で橋梁を保守する 側が変更できる唯一の変量である. 図一3によれば，W $=150 \mathrm{kN}$ の一例を除き, 他は $W<70 \mathrm{kN}$ であるが，施 工実績によれば場所打ちコンクリートブロックでは一単 位が 700 $800 \mathrm{kN}$ ，異型コンクリートブロックでは 200 $\mathrm{kN}$ に及ぶものがある. 一方流失したブロックを後述の 式（13）により安全な領域に入れるためにはブロック重 量を $W=180 \mathrm{kN}$ 程度にしなければならない.これらの 施工実績と判別分析の結果を考慮して, ブロック重量の 最大値の限界として一応 $W<200 \mathrm{kN}$ とするのがよいと 考えられる.

上述の考察は $W$ の最大値に対する適用限界に関する ものであるが，W の最小値についても検討を加える.

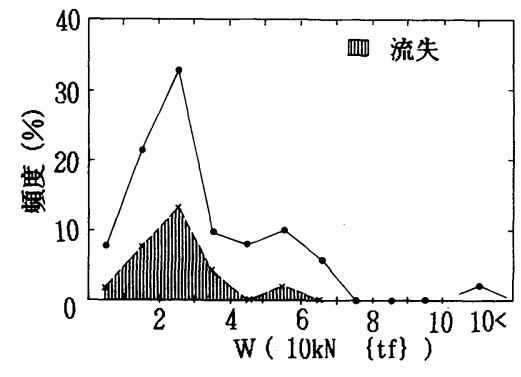

図一3 ブロック重量の頻度分布
それは少なくともブロック重量が限界掃流力以上でなけ ればならないことであり, 式（1）の右辺第 2 項の無次 元掃流力が $\tau *<0.05$ を満足しなければならない. $\sigma / \rho$ $=2.3$, ブロックを球であると仮定すれば,

$W>4370 h^{3} I^{3}$

が得られる.さらに判別分析に用いた統計デー夕を考慮 すれば，式（8）に加えて $W \geqq 5 \sim 10 \mathrm{kN}$ の条件を考慮 するのがよい.

\section{(4) 水 深 $\boldsymbol{h}$}

判別関数の第 4 項は $h$ に比例するが，水深に関連す るものとしてはこのほかに川幅水深比 $B / h$, 摩擦速度 $u_{*}$ がある.ここでは $h$ だけの一変量について適用限界 を考える. 図一 4 によれば, $2 \leqq h \leqq 10 \mathrm{~m}$ に分布しており， 特に異常な傾向はみられない. したがってこれを水深 $h$ の適用限界としてよいであろう.

\section{（5）川幅水深比 $\boldsymbol{B} / \boldsymbol{h}$}

判別関数の第 5 項の $B / h$ も (4) と同様水深に関係 する. $B / h$ の頻度分布は図一5に示すように 3 例を除 いて $B / h<80$ である. このうち, $B / h=129$ の橋梁は 安全グループ $G_{1}$ に属しているにもかかわらず，流失と 判定し誤判別となったが, $B / h=100$ 前後の 2 例は流失 グループ $G_{2}$ に属するものを流失と正しく判別してい る.これらの実情を踏まえ, 川幅水深比の適用限界とし て $B / h \leqq 100$ とすることにした.

\section{（6） $\boldsymbol{u}_{*}, \boldsymbol{h}, \boldsymbol{B} / \boldsymbol{h}$ の関連}

水深が関連する $u_{*}, h, B / h$ は上述の (1), (4) と ( 5 ) のように一変量として適用限界を定めるとともに, 3 項を総合した適用限界を考慮する必要がある，いま， 式（6）の判別関数を水深の関係する項とそうでない項 に分け, 判別点を $Z_{0}=0$ とすれば,

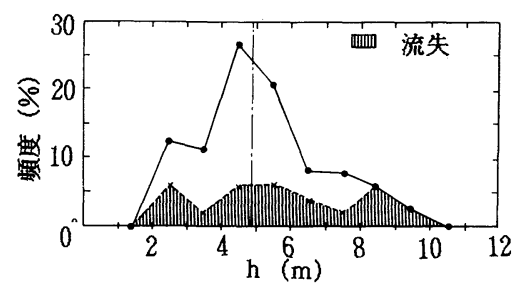

図一4 水深 $\boldsymbol{h}$ の頻度分布

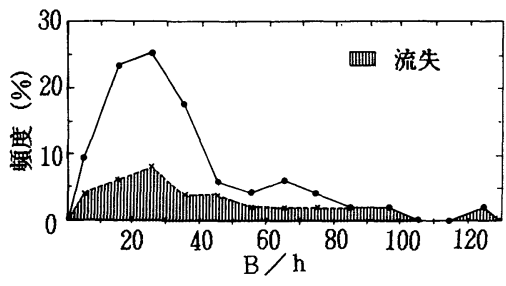

図-5 川幅水深比 $B / h$ の頻度分布 


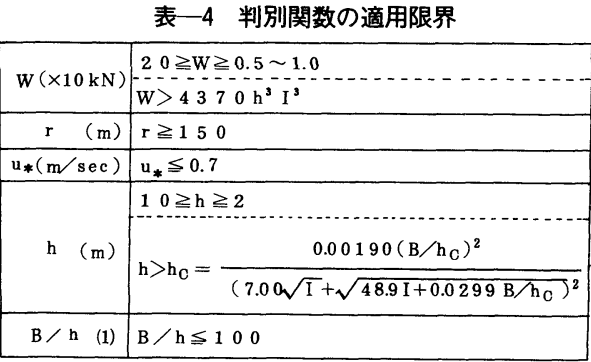

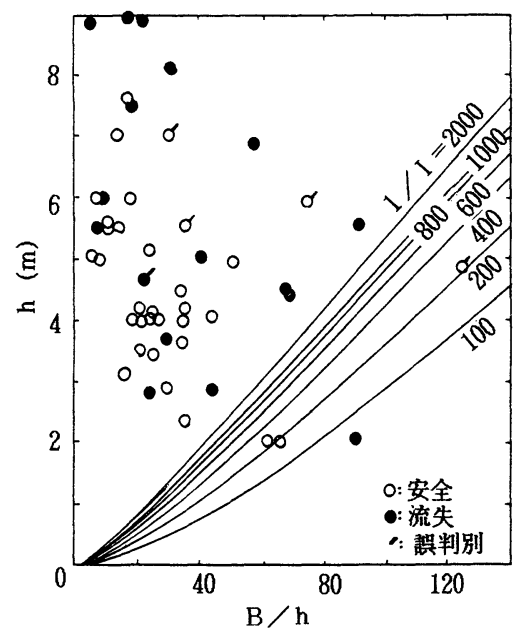

図一6 川幅水深比 $B / h$ と水深 $\boldsymbol{h}$ の関係

$153 / r+0.177 W+3.719=4.47 u_{*}+0.343 h$

$+0.0218 B / h$

となる， $u_{*}$ において径深 $R$ は $B / h$ が大きければ $R=$ $h$ とおくことができることを考慮し, 式（9）の右辺を $y$ とおいて, $h$ で微分すれば,

$d y / d h=7.00(I / h)^{0.5}-0.0218 B / h^{2}+0.343$

となる.ここで $d y / d h=0$ に対して $h^{-0.5}$ の 2 次式とし

て解くと, $y$ の極小値を与える限界水深 $h_{c}$ は,

$h_{c}=0.019\left(B / h_{c}\right)^{2} /\left[7.00 I^{0.5}+\left\{48.9 I+0.0299 B / h_{c}\right\}^{0.5}\right]^{2}$

で与えられる.ここにおいて水深は $h>h_{c}$ の場合のみ 工学的には意味をもつことになる．なぜならば式（9） からわかるとおり, 左辺の $r$ が一定の場合, $h<h_{c}$ の ときには水深 $h$ が大きくなると必要なブロック重量 $W$ が小さくなり，実情に合わなくなるからである，この極 小值 $h_{c}$ は図一 6 に示すようになり, 河床勾配 $I$ の曲線 より上方の領域が判別関数の適用範囲となる.

以上の（1）（ 6 ）の考察をまとめると判別関数の適 用限界は表一4のようになる.

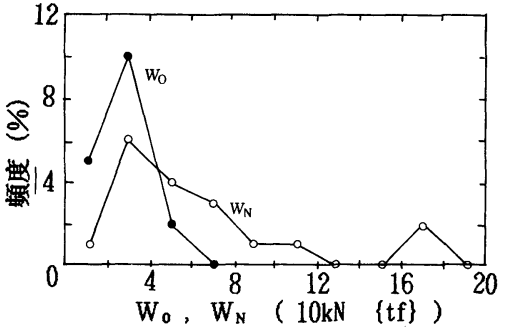

図一7 均衡重量 $W_{N}$ の頻度分布

\section{6. 判別関数によるブロックエの均衡重量}

\section{（1）流失ブロックエの均衡重量}

コンクリートブロック工の洪水時の安定性は式（6） の判別関数に基づいて決定される. 4. で用いた流失し たグループ $G_{2}$ は 17 例であるが，これらのコンクリー トブロック工（ブロック重量 $W_{0}$ ) が流失せずに安全で あるためには, 式 (6) と式 $(7)$ から,

$Z_{0}+0.177\left(W_{N}-W_{0}\right) \geqq 0$

である必要がある．ここに， $W_{N}$ は安全であるための均 衡重量である. 式 (12) から,

$W_{N} \geqq W_{0}-Z_{0} / 0.177$

が得られる.

式（13）に基づいて均衡重量 $W_{N}$ を計算すれば，図一 7 のようになる。これによれば流失した 10〜 $50 \mathrm{kN}$ のブ ロックは，80〜 $100 \mathrm{kN}$ と重くすることにより流失を免 れる可能性が生じることになる.

（2）台風 10 号による東海道線富士川橋梁災害への 適用

上述の流失したコンクリートブロック工の 17 例に加 えて, 昭和 57 年 8 月の台風 10 号による東海道線富士川 橋梁災害の際，施工してあったコンクリートブロック工 の安定性について判別関数を用いて若干の考察を加え る.この橋梁データは本報告で用いた統計データの母集 団 $G_{1}, G_{2}$ のいずれにも入っていないものである. 当橋 梁の $4 \mathrm{P}$ 橋脚は台風 10 号のもたらした富士川の洪水に より倒壊する大被害を受けた。当橋脚付近には $40 \mathrm{kN}$ 異型平面積ブロック 1 層積, $80 \mathrm{kN}$ の直方体型ロックの 乱積みならびに横積み 2 層, そして $120 \mathrm{kN}$ の直方体型 ブロックの乱積みあるいは縦積み（一部 2 層積）が施工 されていたが， $Q=14400 \mathrm{~m}^{3} / \mathrm{s}$ の流量に対して各ブロッ クは一部を残して流失したものである ${ }^{13)}$. 平均河床を基 準にしたときの水深を $h=10 \mathrm{~m}$ としたとき， $B / h=54$ となり，また河床勾配は $I \fallingdotseq 1 / 270$, 径深 $R=5.0 \mathrm{~m}$ で あるから摩擦速度は $u_{*}=0.43 \mathrm{~m} / \mathrm{s}$ 亡なる.また $r=\infty$ とすれば，ブロック重量 $W=40,80,120 \mathrm{kN}$ に対して 式（6） からそれぞれ $Z_{0}=-2.1,-1.4,-0.7$ となり 
式（７）の判別点を参照することにより，これらのブロッ クは流失と判定され, 実際の情況と一致することになる. この洪水に対する必要なブロック重量を式（13）から求 めると $W_{N}=160 \mathrm{kN}$ が得られる. このように富士川橋梁 災害時のブロックの流失についてもきわめて大略の仮定 によるものの, 式 (6) の判別関数は一応正答を与える が， $W_{N}=160 \mathrm{kN}$ に対する実績はないので，このブロッ ク重量が $Q=14400 \mathrm{~m}^{3} / \mathrm{s}$ に耐え得るかどうかは明らか ではない。

\section{7. 判別分析の誤判別の検討}

判別関数で誤判別したデータは，母集団 $G_{1}$ では 5 橋 梁があり, 母集団 $G_{2}$ では 1 橋梁であった. 前者のグルー プは本来安全であったものが, 判別関数により流失と誤 判別されたものであり, 後者は本来流失しているものが, 判別関数により安全と誤判別されたものである.

この誤判別された 6 橋梁のデータを原データに戻って 再調査することは, 判別関数に現われない別の因子を抽 出できる可能性を残すものである. そこでここでは, こ の 6 橋梁について, 若干の考察を加えることにする.

\section{（1）上越線第 1 利根川橋梁}

昭和 57 年 8 月の台風 10 号の出水 $\left(Q=3600 \mathrm{~m}^{3} / \mathrm{s}\right)$ により, 桁下 $2.2 \mathrm{~m}$ (徐行水位) となったが, 本橋梁 (上 り線）の $2 \mathrm{P}$ と $3 \mathrm{P} に$ 施行してあった十字ブロックによ る根固め工の端部がわずかに沈下した程度で，実質上は 変状なしと判断したものである.

しかし判別分析結果は $Z_{0}=-1.44$ で, 当ブロック工 は流失すると判定される.この誤判別になった理由とし ては，橋脚のまわりには張コンクリートを打っていたた め, 橋脚周辺に起こる馬てい型渦による河床の剝離現象 がこの張コンクリートによって抑制されたことによるも の亡考えられる.十分な間詰めのない十字ブロックが橋 脚周辺に並べてあるだけであれば, 判別式の示すように 流失していたかもしれないと想像される.

また写真一1 に示す十字ブロックの不整はブロック側 面の浸食洗掘によって生じた沈下を示しており, ブロッ クが単体として運動したことを物語っている. したがっ て, 十字ブロックではブロック間の連結を十分施し，ふ とん篭などによる間詰めを適時考慮する必要があろう.

\section{（2）信越本線下碓水川橋梁}

洗掘防止工としては右岸側の 11〜 12Pにはくさび型 ブロックを施工し，かつ，左岸側には木工沈床およびふ とん篭工を施工していたが，昭和 57 年 8 月の台風 10 号 の出水 $\left(Q=2600 \mathrm{~m}^{3} / \mathrm{s}\right)$ により析下 $1.5 \mathrm{~m}$ (停止水位) となり，木工沈床とふとん篭工は一部流失したが，くさ び型ブロック $(W=30 \mathrm{kN})$ は流失しなかったものであ る.

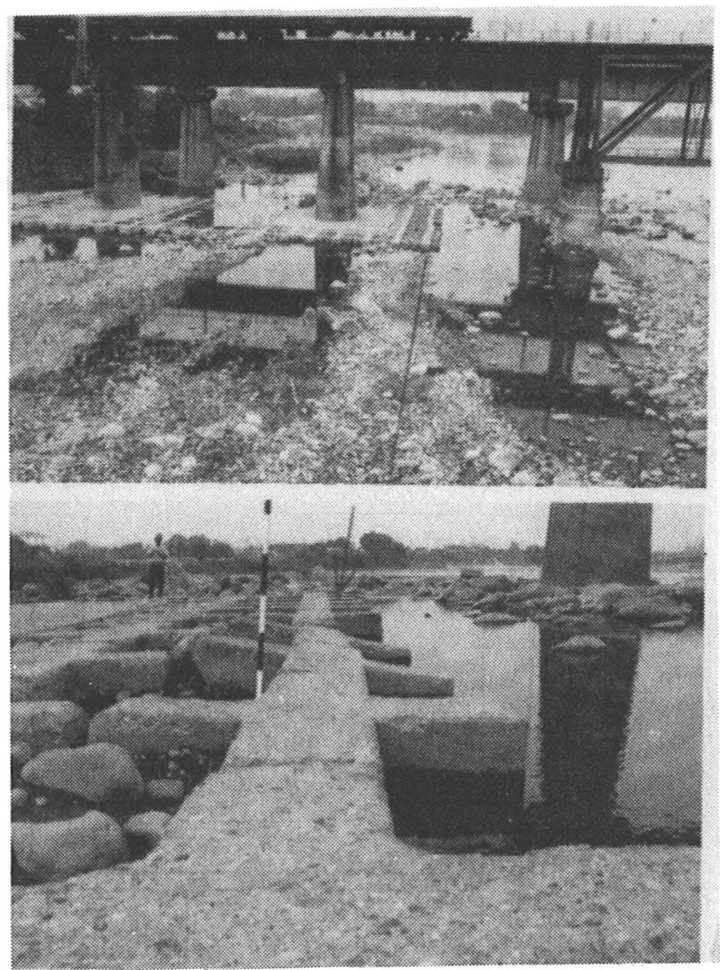

写真一1 上越線第 1 利根川橋梁 3P〜4P の十字ブロックエの 不整

コンクリートブロック工に対する判別関数によれば, 当くさび型ブロックは, $Z_{0}=-0.61$ となり, 流失と判 別されたが，誤判別となった理由としては次のように考 えられる. すなわち，くさび型ブロックの下流側に入っ ていた十字ブロックがくさび型ブロックの下流端におけ る洗掘を防止したために流失に至らなかったということ である、なお，下流端の十字ブロックは不陸を生じてい るが，河床変動になじんだ形状で沈下したことにより， 流失されずにすんだものと判断される.

\section{（3）常磐線阿武隈川橋梁}

本橋梁付近では川幅が $640 \mathrm{~m}$ になっており, 流速も 小さく, 緩流部 $(I=1 / 2000)$ の大河川となっている. 洗掘防止工としては, 図一8に示すように, 昭和 47 年, 48 年に根固工としてくさび型ブロック $(W=13 \mathrm{kN})$ が 施工され，昭和 52 年にはそのブロックのまわりにそだ 沈床工が施工された。昭和 56 年 8 月の台風 15 号による 出水 $\left(Q=3700 \mathrm{~m}^{3} / \mathrm{s}\right)$ に対して桁下 $4.6 \mathrm{~m}$ まで水位が きたが, ブロックの変状はなかったものである.

これに対する判断分析結果は, $Z_{0}=-1.29$ となり流 失と判定され，誤判別となった. 判断分析を行った母集 団 $G_{1}$ と $G_{2}$ に占める当橋梁の $d=1 \mathrm{~mm}$ と $I=1 / 2000$ の関係，あるいは $B / h=129$ の位置づけは，母集団中 


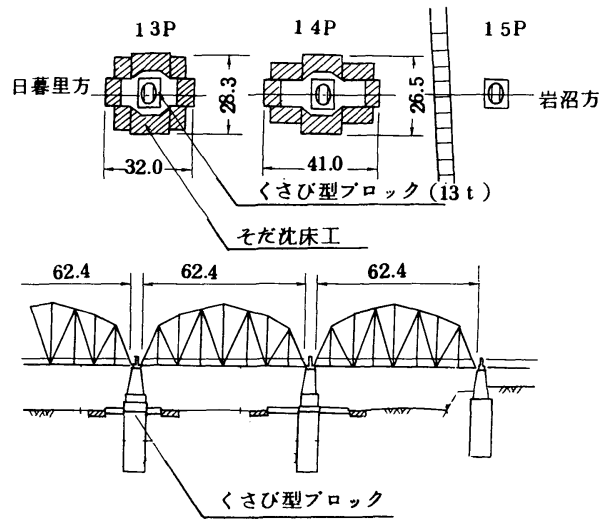

図一8＼cjkstart常蕿線阿武隈川橋梁の平面図と側面図

心からかなり離れている. したがって, 沖積低地の緩流 河川で $B / h$ がきわめて大きい領域に，式（6）の判別 関数を使用することは限界があることを示すものであ る. 5. ( 5 ) ではその適用限界を $B / h \leqq 100$ にしたこと と呼応している.

\section{（4）中央本線多摩川橋梁}

根固め工として昭和 42 年に直方体型ブロック（ $W=$ $60 \mathrm{kN})$ が帯工型式で施工されており，昭和 49 年 9 月 の台風 16 号による出水 $\left(Q=6000 \mathrm{~m}^{3} / \mathrm{s}\right)$ では, 大きな 変状はなかったものである.

一方, 判別分析結果では, $Z_{0}=-0.63$ で当ブロック は流失すると判定し，誤判別となった。しかし上述のよ うに昭和 49 年 9 月の台風では変状がなかったものの, 昭和 57 年 8 月の台風 10 号では桁下水位が前者より 0.3 $\mathrm{m}$ 高くなり，桁下 $3.0 \mathrm{~m}$ まで達しており，18Pと $2 \mathrm{~A}$ 下 流部のブロックの一部が沈下，流失するに至った（この ときの判別関数值は $Z_{0}=-0.65$ である). これらの結 果を考慮すれば, 洗掘防止工は非常に不安定な領域に なっていたものと考えられる．また，ブロック工の施工 状況から若干の考察を加えると, 橋梁は図一-9に示すよ うにイコス工法で周辺が補強されており，それを取り囲 むように直方体型ブロックを施工し，かつその下流方に は古レールを $l=5 \mathrm{~m}$ 打ち込んだふとん篦によってブ ロックの下流部の洗掘を防止するよう工夫されていた

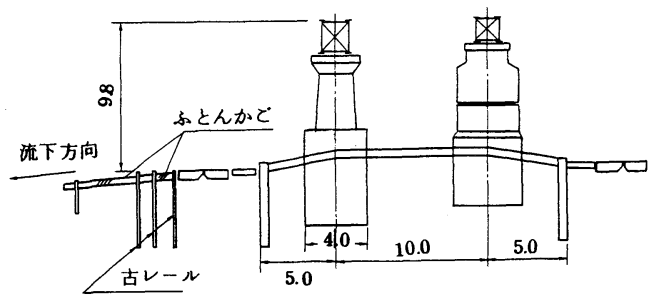

図一9 中央本線多摩川橋梁の断面図
が，これらが有機的に作用して台風時の出水に大きく抵 抗する効果を発揮したものであろう.

\section{（5）山陰本線大屋川橋梁}

大屋川の川幅は, 本橋梁付近では, $200 \mathrm{~m}$ に達し, 河 道は直線である．低水路の幅は $90 \mathrm{~m}$ 程度であるが，河 道中央部には植生のある固定化した砂州があり，みお筋 は 2 つに分かれている. 中央部の $4 \mathrm{P} \sim 6 \mathrm{P}$ と $8 \mathrm{P}$ には昭 和 46 年と 48 年に十字ブロックが，みお筋にあたる $2 \mathrm{P}$ 〜 $3 \mathrm{P}$ と $7 \mathrm{P} \sim 8 \mathrm{P}$ には昭和 54 年にくさび型ブロックが 投入されていた.

昭和 54 年 10 月の台風 20 号の出水 $\left(Q=1800 \mathrm{~m}^{3} / \mathrm{s}\right)$ により桁下 $0.9 \mathrm{~m}$ まで水位が上昇した際， $8 \mathrm{P}$ の十字ブ ロックの一部が沈下し, 流失したが, くさび型ブロック は流失せず，摩耗したと報告されている.

一方, 判別分析結果では, 十字ブロック $W=20 \mathrm{kN}$ については $Z_{0}=-0.65$ と計算され，またくさび型ブ ロック $W=15 \mathrm{kN}$ については $Z_{0}=-0.74$ となり，いず れも流失すると判定される. したがって, 前者の十字ブ ロックについては判別結果は正しいが，後者のくさび型 ブロックについては誤判別となったものである．誤判別 の理由としては，比較的かみ合わせのよいブロックを河 床面より下げて施工し，かつ，下流部に十分長く投入し ていたために，流失を免れ，掃流土砂の多い河川で摩擦 程度でおさまったものと考えられる.

\section{（6）身延線第 1 湯川橋梁}

湯川は本橋梁の下流部 $100 \mathrm{~m}$ の位置で富士川に合流 しており，富士川の河床低下に伴い，本橋梁付近も河床 低下している，そのため，昭和 49 年には $3 \mathrm{P} \sim 4 \mathrm{P}$ にか けて直方体型ブロックを, 昭和 52 年には $1 \mathrm{P} \sim 2 \mathrm{P}$ と $5 \mathrm{P}$ には異型平面型 $(W=40 \mathrm{kN})$ を施工していた。昭 和 57 年 8 月の 10 号台風の出水 $\left(Q=1000 \mathrm{~m}^{3} / \mathrm{s}\right)$ には, 停止水位になる析下 $2.5 \mathrm{~m}$ まで水位が上昇し, $1 \mathrm{P} \sim 2 \mathrm{P}$ の異型平面型ブロックが流失した。現在では流失したと ころは異型平面型 $(W=150 \mathrm{kN})$ を補充している.

一方, 判別分析結果では $Z_{0}=0.44$ となり, 安全であ ると判定され, 流失した母集団 $G_{2}$ では唯一の誤判別と なった. 現場の河床勾配は $I=1 / 200$ の急流であり，河 㦿低下の結果，写真一 2 にみえるようなブロック端部に 大きな落差があるが, このような環境条件は, 式 (6) の判別式では考慮されていない. 特に当獢梁で施工され たブロックは，前後左右の緊結は若干あるものの，層積 みにした場合の上下のかみ合わせは，ブロックの突起に よる前後のかみ合わせだけであり，上層のブロックはか なり動きやすく流失しやすかったものと思われる．本例 は判別式の適当にあたって 1 つの限界を示すものと考え られる. 


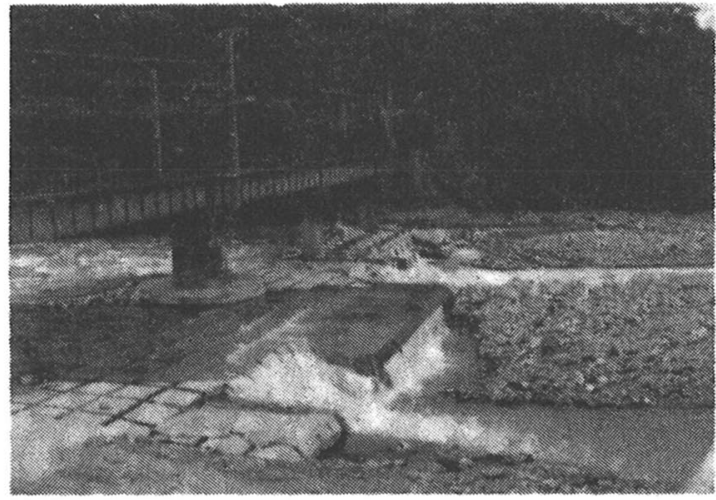

写真一2 身延線第 1 湯川橋梁のブロックエの落差

\section{8. コンクリートブロックエの安定度判定法の 提案}

コンクリートブロックが洪水中にも安定であるかどう かは, 4. の多変量解析の 1 つである判別関数によって, 統計的に判定できることになった.さらに7. の誤判別 のデータに関する検討によれば，ブロックの緊結度，ブ ロックの複合化と可撓性, ブロックの天端高さや層積み, 橋脚のまわりの剝離現象などを十分考慮する必要がある ことも示された。

このような情報を総合的に考虑すれば，より高い精度 でコンクリートブロック工の設計が可能となるであろ う.コンクリートブロック工の設計のプロセスは図一10 のようにまとめられる. まず, 河床の変動, 深掘れや洗 掘条件などの河川特性を勘案して橋脚の根入長を予測 し，それに土質・地質特性と構造物の力学特性を考虑し て橋脚の安定計算を行う.

その結果，洗掘防止工のあることが橋脚の安定上役に 立つことになれば, 防止工の設計が行われる. その際, その川，その橋梁で長年にわたって最良の方法で管理さ れている手法がなければ，ここで述べた統計的な手法に よることになろう.

判別関数は, $u_{*}, B / h, h, r, W$ 5 変量によって, ブロック重量 $W$ を仮定して, 式（6）と式（7）から コンクリートブロック工の安定性が検討される.ただ判 別関数を用いる場合には，5. で示した表一4の判別関数 の適用限界に注意しなければならない.

なお，判別関数によって得られたブロック重量 $W$ は 統計量として与えられたものであるが，設計に供する場 合には線区の防災強度, 橋梁の重要度, 当該河川におけ る洪水の規模（計画高水流量, 洪水の再現期間など）等 を考慮して判別関数で得られたブロック重量 $W$ に若干 の余裕を有するようにすることが望ましい.

以上のように，統計的な判定に立ったコンクリートブ

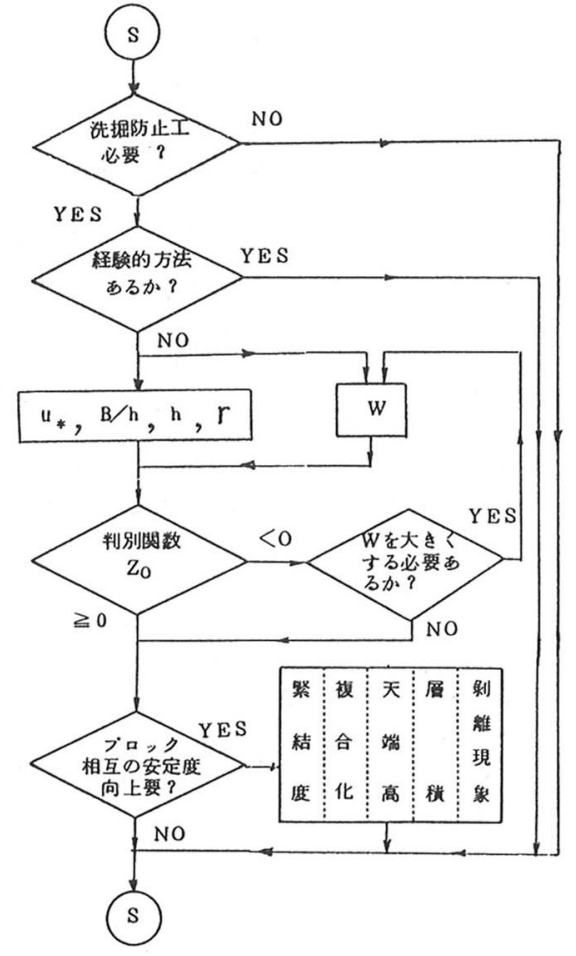

図一10 コンクリートブロックエの設計フローチャート

ロックエの安定性が結論されるに至ったが，これはブ ロック単体に関するものであって，図一10のフロー チャートに示すように, さらに, ブロックとブロックと の相互の安定性について検討を加える必要があるかどう か議論しなければならない。 すなわち, ブロックの緊結 度, 複合化之可撓性, 天端高さと層積み，橋脚のまわり の剝離現象なども考慮する ${ }^{11)}$ 必要があろう.

こうして, 橋脚の安定性を確保するためのコンクリー トブロック工の設計が完了することになる.

\section{9. あとがき}

本報告は, 橋脚の洗掘防止工の 1 つであるコンクリー トブロック工の洪水時の安定性について多変量解析を用 いて検討し，コンクリートブロック工の安定度判定手法 を提案したものである.

安定度を判定する，川幅水深比，水深，摩擦速度，河 川の湾曲度 (河道曲率半径) とブロック重量の 5 変量を 用いた判別関数は，統計的手法によって得られたもので あり，おのずと適用範囲が制限されるものであるが，コ ンクリートブロック工の設計のためのこうした判定法が ほとんどない現状では本報告は十分活用できるものと考 えられる。 
参 考 文 献

1）石原藤次郎：橋脚による河床洗掘に関する実験的研究, 土木学会誌, Vol. 24, No.1, pp. 23 25, 1938.

2) Laursen, E. M. : Scour at bridge crossings, Proc. ASCE, J. of the Hyd. Div., Vol.86, No.HY2, pp.39 $54,1960$.

3) Shen, H. W., Schneider, V.R. and Karaki, S. : Mechanics of local scour supplement, Method of reducing scour, Civil Engrg. Dept. Report, 66, HWS 36, pp. 39 54, Colorado State Univ., 1966.

4) Tanaka, S. and Yano, M. : Local scour around a circular cylinder, Proc. 12th Congress of IAHR, 3, Fort Collins, Colorado, USA, pp. 193 201, 1967.

5）吉川秀夫・福岡捷二ほか：橋脚の洗掘ならびにその防止 に関する考察, 土木学会論文報告集, No. 194, pp. 83〜 90, 1971.

6）宇民 正：橋脚周辺の流れの機構と洗掘防止工法に関す る研究, 京都大学学位論文, 184, 1975.

7）鈴木幸一：橋脚周辺の局所河床変動に関する研究, 京都 大学学位論文, $126,1977$.

8) Breusers, H.N.C., Nicollet, G. and Shen, H.W. :
Local scour around cylindrical piers, J. of Hydraulic Research, Vol.15, No. 3, pp. 211〜252, IAHR, 1977.

9）須賀贲三・高橋 晃ほか：橋脚による局所洗掘の予測と 対策に関する水理的検討，土木研究所資料，No. 1797 , 1982.

10）村石 尚・村上 温ほか：出水による橋りょう下部工の 被災調查について，土木学会年次講演会，1983.

11）岡田勝也・国広敏彦ほか：統計的にみた橋脚の洗掘防止 工(コンクリートブロック工)の安定度判定とその適用性, 鉄道技術研究報告, No. 1287,1985 .

12）村上 温：鉄道橋の洪水時被災機構と安全管理に関する 研究, 鉄道技術研究報告, No. 1307, 1986.

13）東海道本線富士川橋りょう対策技術委員会報告書, 日本 鉄道施設協会, 1983 .

14）吉川秀夫：流砂の水理学, 丸善, pp. 313 341, 1985.

15）中川博次：河川構造物の被災形態とその事例集, 河川構 造物災害調查研究会, 1987.

16）芦田和男 - 高橋 保 - 道上正規：河川の土砂災害と対策, 森北出版, 1983.

（1988.8.5 • 受付） 